\title{
SOCIAL SUPPORT FOR PERSONS UNDER SUPERVISION PROBATION
}

\author{
Sofiia Oshurkevych ${ }^{1}$, Volodymyr Proskura ${ }^{2}$ \\ Lviv Polytechnic National University, Lviv, Ukraine \\ ${ }^{1}$ Student of bachelor program "Social Work", of Department of Sociology and Social Work, \\ ${ }^{2}$ Candidate of Social Sciences, Associate Professor of Department of Sociology and Social Work
}

Background: Today, the use of various types of probation is gaining popularity around the world. In particular, the active development of this method of punishment as a supervisory probation is explained not only by higher efficiency in terms of reducing recidivism, but also by a number of benefits for both the public and the offender himself.

Purpose: to study the process of social support for persons to whom probation is applied.

Methods: comparative analysis and generalization of sources on the problem of research of social support of persons to whom probation is applied. Terminological analysis that provides an understanding of the subjects and subjects of the topic under investigation by identifying and clarifying the meanings of the underlying concepts. Quantitative and qualitative method in the form of content analysis of document study, which allows to obtain a general conclusion from different works and articles, to process this information, to organize it and to draw own conclusions.

Results: The basis for the application of supervisory probation is the law defines the relevant court decisions (sentence of court, court order) or an act of pardon, whereby a sentence of imprisonment or restraint of liberty is replaced by a softer one.

The essence of social support for persons to whom this type of probation is applied lies in the implementation by the relevant state body of the observance of the duties stipulated by law and imposed by a court decision on the convicted. This is achieved through the implementation of an individually designed plan of work with persons, taking into account the risk of repeated violation of the law, which includes:

- providing necessary social, medical, psychological, educational and legal services;

- application of special probation programs.

Conclusions: Social support for offenders is a major feature of supervisory probation. Thus, social support is manifested not only in the above services, but also in the conduct of social and educational work, which provides for a differentiated approach in providing counseling, psychological and other types of assistance, as well as promoting employment; involvement in learning; participation in educational activities and socially beneficial activities; conducting individual-preventive work.

Keywords: Supervisory Probation, Social Support, Sentenced Persons, Probation Programs.

На сьогоднішній день застосування різних видів пробації набирає все більшої популярності по всьому світу. Зокрема, активний розвиток такого способу покарання як наглядова пробація пояснюється не лише вищою ефективністю з точки зору зниження рецидивної злочинності, але $\mathrm{i}$ низкою переваг як для суспільства, так і для самого правопорушника.

Мета: дослідження процесу соціального супроводу осіб, до яких застосовується наглядова пробація.

Для дослідження даної теми використано наступні методи:

- порівняльний аналіз та узагальнення джерел із проблеми дослідження соціального супроводу осіб, до яких застосовується наглядова пробація;

- термінологічний аналіз, що забезпечує розуміння сутності досліджуваних суб'єктів та об’єктів даної теми за допомогою виявлення та уточнення значень основоположних понять;

- кількісно-якісний метод у вигляді контент-аналізу вивчення документів, що дозволяє отримати загальний висновок з різних праць та статей, опрацювати дану інформацію, систематизувати їі та зробити власні висновки.

Наглядова пробація полягає у здійсненні наглядових та соціально-виховних заходів щодо: 
- засуджених до покарань у вигляді позбавлення права обіймати деякі посади, а також займатися певною діяльністю, громадських та виправних робіт;

- осіб, яким покарання у вигляді обмеження волі або позбавлення волі на певний строк замінено покаранням у виді громадських робіт або виправних робіт;

- осіб, звільнених від відбування покарання 3 випробуванням, звільнених від відбування покарання вагітних жінок і жінок, які мають дітей віком до трьох років;

- направлення засуджених до обмеження волі для відбування покарання до виправних центрів (Седхем, Дж., \& Октіган М. 2017).

Підставою для застосування наглядової пробації закон визначає відповідні судові рішення (вирок суду, ухвала суду) або акт про помилування, яким покарання у виді позбавлення або обмеження волі замінено на більш м'яке (Ягунов, Д.В., (2007)).

Сутність соціального супроводу осіб, до яких застосовується даний вид пробації, полягає в реалізації відповідним державним органом дотримання обов'язків, що визначаються законом та покладені рішенням суду на засуджених. Це досягається завдяки виконанню складеного індивідуально плану роботи 3 особами 3 урахуванням ризику повторного порушення закону, що включає у себе:

- надання необхідних соціальних, медичних, психологічних, освітніх та юридичних послуг;

- застосування спеціальних програм пробації (Сайт Міністерства юстиції України).

Отже, доцільно зазначити, що соціальний супровід правопорушників є головною відмінною особливістю наглядової пробації. Таким чином, соціальний супровід проявляється не тільки у вище перерахованих послугах, але і у проведенні соціально-виховної роботи, що передбачає диференційований підхід під час надання консультативної, психологічної та інших видів допомоги, а також сприяння працевлаштуванню; залучення до навчання; участь у виховних заходах та соціально корисній діяльності; проведення індивідуально-профілактичної роботи.

\section{References}

Sedham, J., \& Octigan M. (2017). Essentials of professional activity of probation staff: a training manual for probation staff. Kiev: Supporting Justice Reforms in Ukraine.

The official site of Probation of Ukraine. (n.d.). Supervisory Probation. Access mode: http://www.probation.gov.ua/?page $\mathrm{id}=131$

Website of the Ministry of Justice of Ukraine. (n.d.). Probation Service. Access mode: https://web.archive.org/web/20170203182501/https://minjust.gov.ua/en

Yagunov, DV, (2007). Probation Service: concept, principles of activity, organizational structure. Odessa: Odessa Regional Institute of Public Administration.

\section{Список використаних джерел}

Офіційний сайт «Пробація України». (n.d.). Наглядова пробаџія. Режим доступу: http://www.probation.gov.ua/?page id=131

Сайт Міністерства юстиції України. (n.d.). Служба пробації. Режим доступу: https://web.archive.org/web/20170203182501/https://minjust.gov.ua/ua

Седхем, Дж., \& Октіган М. (2017). Основи професійної діяльності персоналу органу пробації: навчальний посібник для персоналу органу пробачії. Київ: «Підтримка реформ у сфері юстиції України».

Ягунов, Д.В., (2007). Служба пробації: концепція, засади діяльності, організаційна структура. Одеса: одеський регіональний інститут державного управління.

\section{Контактна інформація:}

Ошуркевич Софія Ігорівна oshurkevych.sofija@gmail.com

Проскура Володимир В'ячеславович

proskura.v@gmail.com 